Psychology of Language and Communication 2014, Vol. 18, No. 2

DE GRUYTER

OPEN

DOI: $10.2478 /$ plc-2014-0012

AGATA TARWACKA-ODOLCZYK ${ }^{1}$, PIOTR TOMASZEWSKI ${ }^{2}$, AGNIESZKA SZYMAŃSKA ${ }^{3}$, BARBARA BOKUS ${ }^{2,4}$

1 Tots' Academy, Warsaw

${ }^{2}$ University of Warsaw

${ }^{3}$ Cardinal Stefan Wyszyński University, Warsaw

${ }^{4}$ University of Social Sciences and Humanities, Warsaw

\title{
DEAF CHILDREN BUILDING NARRATIVE TEXTS. EFFECT OF ADULT-SHARED VS. NON-SHARED PERCEPTION OF A PICTURE STORY
}

\begin{abstract}
This paper discusses the communicative competence of deaf children. It illustrates the process in which such children build narrative texts in interaction with a deaf teacher, and presents the diversity of this process due to the shared vs. non-shared perception of a picture - the source of the topic. Detailed analyses focus on the formal and semantic aspect of the stories, including the length of the text in sign language, the content selected, information categories, and types of answers to the teacher's questions. This text is our contribution in memory of Professor Grace Wales Shugar, whose idea of dual agentivity of child-adult interaction inspired the research presented here.
\end{abstract}

Key words: narrative text, narrative discourse, deaf children, sign language, information categories, old-new content

\section{Introduction}

A text is best regarded as a SEMANTIC unit, a unit not of form, but of meaning. A text does not CONSIST OF sentences, rather it is REALIZED BY, or encoded in sentences (Halliday \& Hasan, 1976, p. 2) uttered to transmit information in social situations. These utterances are constructed within a larger organized dis-

Address for correspondence: Barbara Bokus and Piotr Tomaszewski, University of Warsaw, Faculty of Psychology, Stawki 5/7, 00-183 Warszawa, Poland. E-mail: bokus@al.uw.edu.pl; piotr.tomaszewski@ psych.uw.edu.pl 
course entity. In the present paper we deal with narrative discourse treated as a pragmatic unit of language. The product of such discourse -narrative text - is a verbal representation of changing reality (Labov, 1972), and can be defined as a chain of reference situations (Shugar, Bokus, \& Smogorzewska, 2013). Producing a narrative text is a process in which content is added. Each piece of content is a "building block" of a semantic structure of lesser or greater complexity. Children can draw upon different sources of such semantic material, accessible directly or indirectly, switching between the two types of source (Bokus \& Shugar, 1995). Social context conditions and adult practices are vitally involved in the success of these processes. Many researchers contribute to solving the puzzle of how young children begin, and proceed to build up, the semantics of their language, enabling them to engage in conversations of many kinds with both adults and peers, on their way toward the formal educational process (Nelson, 2014, p. 102).

Approaching children's language acquisition from the point of view of discourse theory, Grace Wales Shugar (1995) assumes that the acquisition and development of language use consists in mastering the skill of participating in discursive processes. These processes unfold within structures created by the participants of interaction. Before children are able to produce texts on their own, they co-create texts with adults, performing certain operations on an adult's utterances (Shugar, 1978, 1998). Trevarthen (1980) in his work on the foundations of intersubjectivity, emphasized that children have an inner, innate motivation to acquire knowledge from others. In Shugar's view, however, this idea is incomplete. What would be the source of a growing motivation to acquire knowledge from others? According to Shugar, such motivation could grow due to those others showing the child that they, too, acquire knowledge from the child (see Babska \& Shugar, 1984). It is only when children can show what they know in their own way, and when that child knowledge is received and used in a discourse process, that we can expect a child's inner motivation to acquire knowledge from others to be maintained and to become a driving force of the child's further development (Shugar, 1995, p. 233). The ways in which knowledge is transferred, received and assessed define different degrees of children's freedom of choice of forms of participation in learning, teaching and upbringing processes, as well as forms of communication between child and teacher (see Gurycka, 1989).

\section{Social structures of children's narrational activity. The role of the adult's access to the topical source}

From the perspective of the theory of action, the subjective nature of human beings consists in the fact that, first of all, they have the capacity to identify their objective situation and understand the significance of its individual elements. This enables them, secondly, to transform situations into tasks for completion. Tasks, meanwhile, lead to performance, to the development of activity in a given 
direction, and this is where we have to seek the third manifestation of human subjectivity, namely in the fact that humans are able to interpret and select continually flowing new stimuli in terms of the task in hand (Tomaszewski, 1984, p. 132). In their article devoted to narrative analysis, Labov and Valetzky (1967) emphasized that narratives are usually told in answer to some stimulus from outside (ibid., p. 34), and narrators have a personal interest in making such a response (Bokus \& Shugar, 1998, p. 76). Considering children's activity, Cazden (1970) noted that at any given moment, a child decides what to do (to speak or be silent, to adopt this or another communicative intent, to express this or another idea, in this or another form). The options the child selects will be a function of the characteristics of the speech situation as he or she perceives it on the basis of past experiences (Cazden, 1970).

In 1979, continuing the above research issue, Bokus and Shugar phrased the following questions for study: What configurational changes in given social situations are decisive in producing the important differences in child's speech? Can we discover, through experimental manipulation, the minimal and manipulable factors in a conversational situation which will produce reliable changes in the way the child will talk to a listener? (see Bokus \& Shugar, 1998, p. 76).

One key factor in adult-child conversational situations was chosen: the adult's access (or not) to the topical source, or more precisely: adult-shared vs. non-shared perception of a picture. This factor enables narrative situations to be differentiated in terms of the possibilities for the child to realize the informational function of language. This function emerges relatively early during development and, as Halliday (1975) points out, serves the communication of content that is new to the listener.

In the light of these considerations, a child's narrative text can be analyzed not only as a function of:

- the child's general knowledge on categories of information needed to structure the story (Snow \& Goldfield, 1982),

- the child's specific knowledge about a given picture, needed to fill the network of information categories with content,

but also as

- the child's knowledge about the interactional situations, in which the child perceives his or her narrator's role in terms of greater or lesser freedom to choose content known ("old") or unknown ("new") to the listener.

Bokus and Shugar $(1979,1998)$ have shown that differences in the organization of "old - new" information stemming from the situational conditioning of the "child - picture - adult" relationship are accompanied by clear differences in the structure of narrative texts produced by children. Already at age three to four, children have the capacity to account for their partner's position in a communication situation. Their stories about a picture are very different, depending on whether the adult partner in the discourse has perceptive access 
to the picture or not. In situations where the child becomes the sole competent source of new information about the picture, the child's contribution to creating a narrative text is much more extensive and more complex. This is true on the story's lexical, syntactic and semantic levels. The studies (encompassing Polish preschoolers within the intellectual norm) also showed narrators' different expectations about the listener (here: teacher) in terms of his/her perception of story information: in one situation (non-shared perception of a picture), open to the "new", in the other (shared perception), controlling the "old" (known to both participants).

Children's drive to provide adult listeners with information that is new to them was confirmed in a replication of the study in a group of Australian children (Turnbull, 1980). Similar results were obtained in a study in which the child-adult dyad was replaced with the child-child peer dyad (Modzelewska, 1996; see Bokus \& Shugar, 1998). The same research procedure was also applied in studies involving children with mild mental retardation in a free play situation (Bałachowicz, 1996), and in studies of emotionally disturbed children in a test situation (Terman-Merrill test; see Bokus, 1991a). All these studies on children's narrative in interaction with adults or peers were conducted for spoken language. The children in the studies came from the hearing population. The important question now is whether the same correlations are found in the population of deaf children who use sign language as their first language.

The distinguishing feature of the present study is that it was conducted on a group from a different population (deaf children) and that it involved a different modality of the language (sign language) in which the stories were told (visualgestural modality).

\section{The research problem}

The main research question in the present study is this:

\section{In deaf children using sign language, does the adult's seeing the picture story, or not, significantly affect the way the children build a narra- tive text?}

There are no guidelines regarding deaf children's narratives that could be the basis for hypothesis generation. However, conclusions from studies on hearing children can be helpful, enabling us to design detailed research questions and related hypotheses.

Below are the research questions and hypothetical answers:

1) Are there differences in the length of narrative texts produced by the same deaf children depending on whether the (adult) listener looks at the picture with the child (here: shorter stories) or not (here: longer stories)? 
2) Do changes in the "child - picture - adult" interaction system lead to changes in the content produced? (We expected more statements on content going beyond perception data when the listener does not have access to the pictures. When the listener does have such access, the child concentrates more often on what lies within the shared field of attention.)

3) In what information categories does a deaf child provide content about a picture? Are categories of information elaborating the space of events activated more often when the adult has only the child as a source of knowledge on what happened to the characters in a picture story?

4) When answering the question of the adult looking at the picture with the child (narrator), do children react more often by repeating their earlier statements or repeating the question? (We expect children to react with fewer such repetitions when the adult cannot see the picture.)

\section{The subjects}

The study involved 24 deaf children and a deaf teacher whom they knew and who knew sign language. All children were in the first and second grade of elementary school at the Rev. Falkowski Institute for the Deaf in Warsaw.

The study was carried out in two 12-person groups. One group comprised deaf eight- and nine-year-olds taught according to the bilingual model that includes Polish Sign Language (polski język migowy - PJM) and Polish. The other group comprised deaf children taught with a combined method that uses the Speech and Signed System (system językowo-migowy - SJM). The SJM method involves using spoken language simultaneously with signs taken from PJM and grammatical structures typical for spoken Polish (Tomaszewski, 2010, p. 8). Due to the wider age scale in these classes, the children ranged in age from eight (one child) to eleven years (two children)

Because most children in the study (15 out of 24) had hearing parents and learned sign language later, as compared to deaf children of deaf parents, it was decided (after consulting experts) that children aged eight and over would be studied. This age was accepted as optimal for the task (narration). From the age of eight, deaf children (even those who came into contact with PJM late) are proficient enough in sign language to be able easily to tell the teacher about a picture in two experimental interactive situations. This was precisely the subjects' task. The children knew the deaf teacher (who took part in the study and was an expert on PJM) from school and/or extracurricular activities.

\section{The experimental situations}

Two play-task situations were set up in each group (separately in the PJM group, separately in the SJM group), separated by a period of one week. 


\section{Situation S+}

The deaf child told (using sign language) a familiar adult (who knew PJM) the content of a picture book accessible to the perception of both (the book was laid on the table at which the child and the teacher were sitting).

\section{Situation S-}

The deaf child told (using sign language) a familiar adult (who knew PJM) the content of a picture book accessible only to the perception of the child (the book was on a stand that restricted the teacher's field of vision). The study (both S+ and $\left.\mathrm{S}^{-}\right)$was recorded on video.

In S+ and in S- the adult entered into a dialogue with the child. Due to the visual nature of sign language, eye contact was maintained in both situations. The set of the teacher's statements was predefined and included:

- starting the interaction (instructions given to the child)

- keeping up the child's initiative in speaking (behaviors showing the listener was interested, such as nodding, saying "mhm", maintaining eye contact with the child)

- showing interest and curiosity (questions like "why?")

- concluding the interaction after the child's final statement

\section{Organization and course of the study}

The study was conducted at the Rev. Falkowski Institute for the Deaf in Warsaw. Two rooms were used. In the first room the children played, drew envelopes with numbers to decide who would be the narrator and engaged in their own activities. The children went into the other room one by one, in the order of the draw, and there told the teacher a story about what happened to the characters in a picture story (Tarwacka, 2004). Stories A and B ${ }^{1}$ (see Appendix 1) are from Bokus' research on hearing children's narrative discourse (Bokus, 1991b).

The children were randomly split into four subgroups of six children each (4 $\times 6$ =24). Each subgroup included three children taught using the bilingual method (PJM and spoken Polish) and three children taught using the combined method involving the SJM. The study was carried out in two test series, as shown in Table 1.

This means that children from subgroup one told the teacher about picture A in situation S+ (shared perception of the picture), and a week later the same children recounted picture B in situation S- (isolated perception of the picture). Thus, 24 children (12 taught with the bilingual method and 12 with the SJM combined method) took part in situation S+. The same number (the same children) took part in situation S-. A total of 48 observations in situations $\mathrm{S}+$ and S- were gathered.

\footnotetext{
${ }^{1}$ The stories were prepared on the basis of pictures from the book for children entitled Öt törtonét két manóról (Marta Kende, 1984).
} 
Table 1. Study pattern

\begin{tabular}{llcccc}
\hline & & \multicolumn{4}{c}{ Subgroups } \\
\cline { 2 - 5 } & & 1 & 2 & 3 & 4 \\
\hline \multirow{2}{*}{ Study series } & I & A (S+) & A (S-) & B (S+) & B (S-) \\
& II & B (S-) & B (S+) & A (S-) & A (S+) \\
\hline
\end{tabular}

Efforts were made during the study to create a natural play-task situation, and to get the children interested and eager to take part in the study. Judging by the children's reactions, this aim was achieved. The children treated taking part in the study like a game, even a sign of special recognition. Of course one important element affecting their willingness was the prospect of a reward: a chocolate surprise egg.

The discourse between the children and the adult was recorded on video.

\section{Analysis methods}

The material for empirical analysis was provided by videos of the experimental situations and the children's statements recorded in PJM. On the basis of the interactions with the children during the study and the video recordings, the teacher of the Institute for the Deaf in Warsaw, an expert on PJM, wrote down the narrative texts built by the deaf children in interaction with the adult. This record included both gestures and PJM simple signs (one-class system of language) and PJM composite signs (two-class system of language).

Working with this material, three raters divided the text into single statements, i.e. linguistic units that are not only actualizations of sentences, but also of speech acts (Kurcz, 2005) expressing the speaker's intention.

In a phonic language, an utterance is a closed, complete intonation structure with signs marking the beginning and the end. Due to the spatial character of the sign language analyzed in the present work, when dividing the text the following criteria were applied:

- breaks occurring between signs or gestures;

- changes in the location of signs in space;

- facial expressions (in sign language, facial expression can play a similar role to changing intonation in spoken language - separating individual statements).

A comparative analysis was performed on the children's statements in situation S+ and situation S- (cf. the sample stories in Appendix 2; transcription conventions: symbols used to write a sign system are in Appendix 3).

The narrative texts were analyzed in formal terms (story length) and in semantic terms (the content being provided by the pictures or not, types of in- 
formation categories in which the content was provided, types of explanations when responding to "why?" questions).

Story length (S_W_sum) was measured by the number of statements (signs and gestures). A comparison was also made between the number of spontaneous statements (S_Wsp_sum) and statements prompted (S_Wpp_sum) by the adult's questions in situations $\mathrm{S}+$ and $\mathrm{S}-$.

As regards semantic analysis, we analyzed the statement content (how it related to the content provided by the pictures):

- content present $\left(S \_W_{-} 01\right)$ in a picture, e.g.: ODBIJAĆ-PIEKA 'bounce the ball'; ŻÓŁTE UBRANKO 'yellow clothes';

- content present in a picture with an added interpretation (S_W_02), e.g.: PŁAKAĆ+++ 'cry so long'; CIESZYĆ-SIE ' to be pleased'/'to be glad';

- new content not present in a picture (S_W_03), e.g.: PICIE KUPIĆ 'buy drink' WYCIĄGNĄĆ-kogoś 'pull somebody out (e.g. of water)'.

This content was also analyzed within spontaneous statements (from $S_{-}$Wsp_01 to $S_{-} W_{s} p_{-} 03$ ) and after questions (from $S_{-} W p p_{-} 01$ to $S_{-} W p p_{-} 03$ ).

The children's stories were also analyzed in terms of the information categories contained in statements. The classification was modeled on the information categories suggested by Snow and Goldfield (1982) and modified and expanded by Shugar and Bokus (1988), as follows:

1. Item labels, $S \_K i$ 01. This category answers the questions: What is it?, Who is it? (e.g. IX-bear picture MIŚ 'this bear'; KAWA IX-coffe picture 'this coffee')

2. Item elaborations $S_{-} K i_{-} 02$. This information answers the questions: What is it (are they) like?, What kind is it?, How many were there?, What color is it? etc. (e.g. MIŚ DUŻY 'big bear'; BRĄZOWY SIERŚĆ 'brown fur')

3. Events $S \_K i$ 03. This category answers the questions: What took place?, What happened?, What is happening?, How are things (what are the conditions)? (e.g. IX-boy picture MOKRY 'he got wet'; PIŁKA BAWIĆ-SIĘ ' play ball')

4. Event elaborations $S \_K i$ OO - further describing identified events in terms of time, place, agent, object (objects) of actions, structure of actions etc. (e.g. ODBIJAĆ-PIŁKA+++ 'bounce ball so long'; IX-pro3p WYCIĄGNĄĆ-go WODA 'He pulls him out of the water')

5. Explanations $S \_K i \_05$. This category of information answers the question "Why?" (e.g. IX-pro3p PRZYKRYĆ-go NHS:BO CHORY 'S/he covers him because he is sick'; GARDŁO CHORY NHS:BO WPAŚĆ-DO WODA '(He has) a sole throat because (he) fell into water')

6. Evaluations $S_{-} K K_{-}$06, e.g. smart-stupid, good-bad, nice-mean, fast-slow etc. (e.g. SMACZNE 'tasty'; DZIEWCZYNKA LUBIĆ GEASKAĆ-misio 'Girl likes stroke bear')

7. Reference to one's own experiences (non-observed in the material from deaf children). 
The narrative texts produced by the deaf children were additionally analyzed in terms of the types of explanations produced in response to "why?" questions asked by the adult. This classification is based on that of Geppertowa (1968) as expanded by Shugar and Bokus (1988) and includes the following types of explanations:

I. Justification and motivation(S_Kip_01), e.g. NIE-MA-NIKOGO, CHCE DZIECI, PŁAKAĆ+++ 'There is no one. (Bear) needs children. (Bear) cries all the time.'

II. Cause explanation (S_Kip_02), e.g. GARDEO CHORY NHS:BO WPAŚĆDO WODA '(He has) a sole throat because (he) fell into water.'

III. Proof and logic (S_Kip_03), e.g. MIŚ PŁAKAĆ, LUBIĆ MAMA 'Bear cries. (Bear) likes mommy.'

IV. Repetition (S_Kip_04).

This includes repetition of part or all of a child's earlier statement, as well as repetition of questions (e.g. teacher - "DLACZEGO MIŚ PŁAKAĆ DLACZEGO?" 'Why does bear cry?', child - "DLACZEGO MIŚ PŁAKAĆ” 'Why bear cries').

\section{Analysis results}

Three analyses were used to check the differences between the children's participation in situations S+ and S-: a) dependent samples test, b) logistic regression, c) the construction of a decision tree using an artificial intelligence algorithm - the Classification and Regression Tree (C\&RT).

\section{Results of the test for dependent samples}

The Shapiro-Wilk test showed that the distributions of all the variables deviate from a normal one in situation S+ and/or S-. The non-parametric Wilcoxon test for dependent samples was used for these variables.

The results show that the length of stories, measured by the number of signs and gestures $\left(S_{-} W_{-}\right.$sum $)$, is significantly different depending on the type of experimental situation, S+ or S-, in which the same children were placed.

In S+, children used 14.5 signs and gestures on average ( median $=14.5$ ), in S$m e=22$. The differences are statistically significant: in the test for dependent samples, Wilcoxon $Z=-3.276, p=0.001$ (two-way significance) ${ }^{2}$. Thus, when the adult could not see the picture, the children said significantly more.

Differences were also found in the number of spontaneous signs and gestures, S_Wsp_sum (the median in S- was 12.5; the median in S+ was 10), Wilcoxon $Z=2.194, p=0.028$, and also in the number of signs and gestures in response to the adult's statements, $S \_$Wpp_sum (Wilcoxon $Z=2.850, p=0.004$ ), to the advantage of situation $S-$ (the median for $S-$ was 7 ; the median for $S+$ was 4.5 ).

\footnotetext{
${ }^{2}$ We compare the median values because the Wilcoxon test used in the study is based on median comparisons.
} 
Figure 1. Children's statement median values in situation S+ and S-

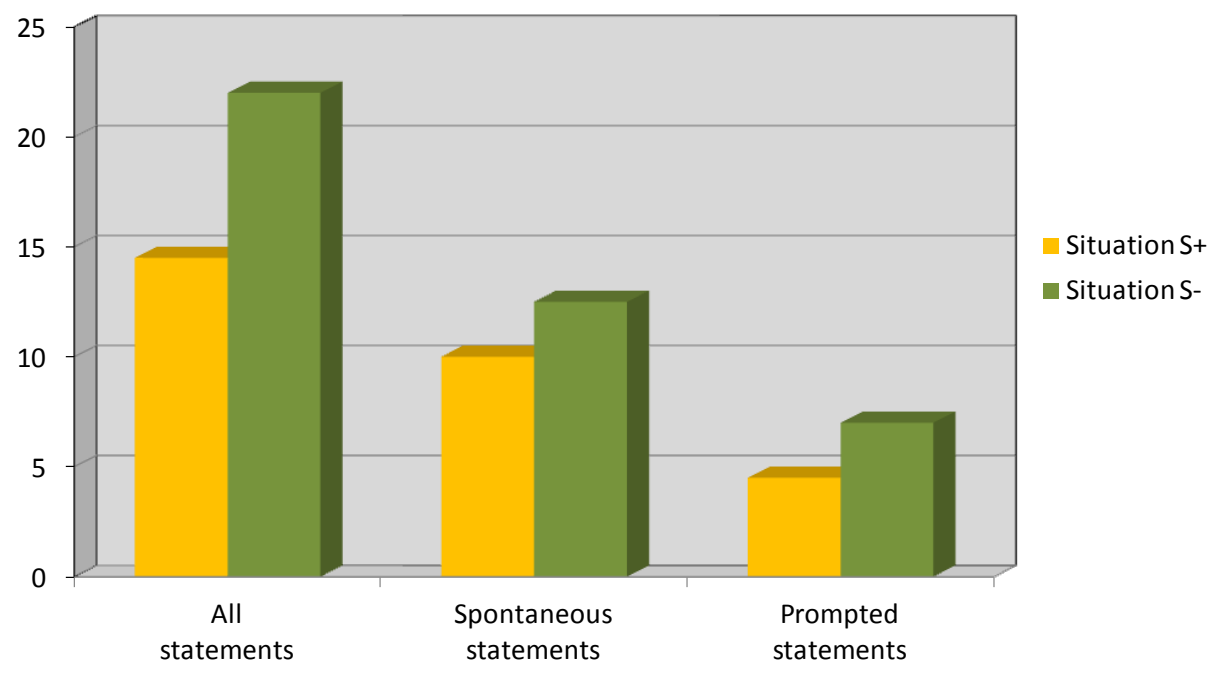

On the other hand, no statistically significant differences were found for the questions the children were asked, (S_Kip_sum) in situation S+ and S- (the median was 2.5 in both situations, Wilcoxon $Z=1.642, p=0.101$ ).

Figure 1 illustrates the average lengths of children's narrative texts in $S+$ and $\mathrm{S}$ - (all statements) and the average number of statements (gestures and signs) appearing spontaneously or in response to the adult's questions (prompted statements).

\section{Semantic analysis of statements coding content present in the pictures, content present with interpretation, and new content}

Analysis of the content in the products of narrative discourse focused on the number and type of linguistic units (statements) produced in succession. As shown above, building narrative texts in a non-shared perception situation, children produce more statements, regardless of the type of content these include.

The semantic analysis highlighted the fact that both present content, and present content with interpretation, have the pictures as their source, accessible to perception "here and now", which sets them clearly apart from the third type of statement content, i.e. that classified as new content. In this last case, children build their stories referring to information that is not contained in the pictures - to situations shifted in time and/or space. They move outside the "here and now". They also refer to their own knowledge on the possible inner states of the characters in the narrative. 
Figure 2. Children's statement median values in situation $\mathrm{S}+$ and $\mathrm{S}-$, with division into statements providing content present in the pictures, content present with added interpretation, and new content (not present in the pictures). The test for dependent samples did not reveal differences in the number of statements

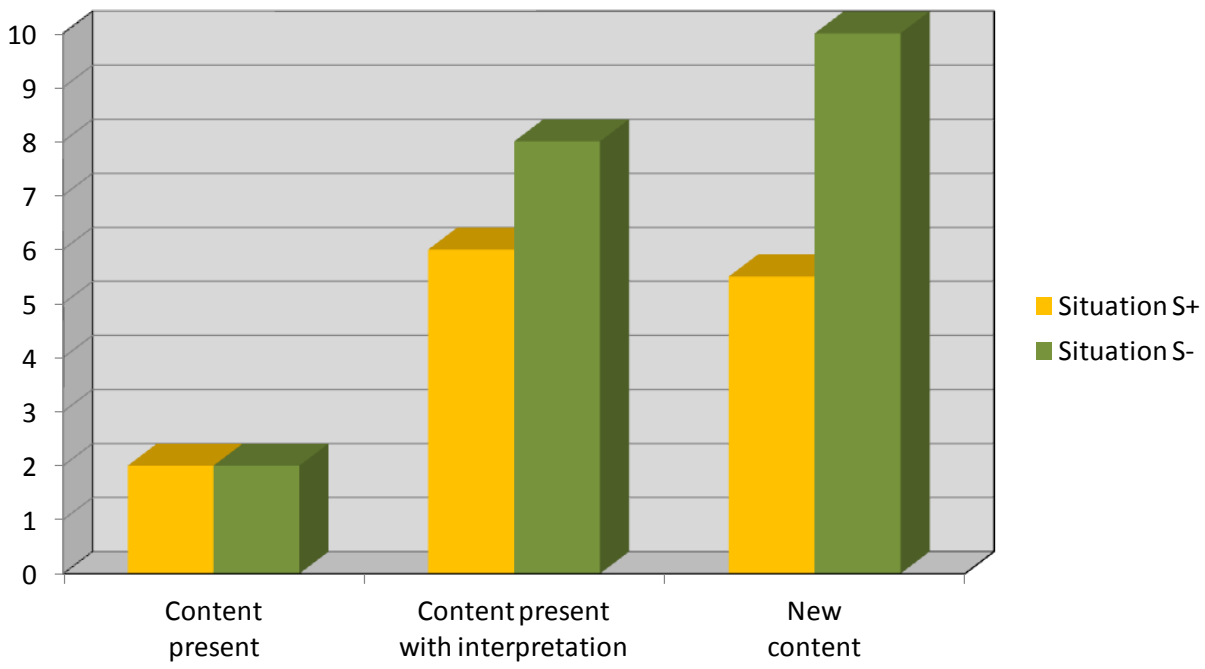

Taking into account these differences, a comparison was made between statements with content based on the pictures (present, and present with interpretation) and content not present in the pictures (new content).

Figure 2 shows the median numbers of statements with content present in the pictures, content present with added interpretation, and content not present in the pictures (new content) in situations S- and S+.

The test for dependent samples did not reveal differences in the number of statements concentrating on content from the pictures (S_W_01) in S- (median: 2) and $S+$ (median: 2 ). In both situations children equally often referred to content present in the pictorial material. A difference was that in situation $S-$, compared to $S+$, the number of statements $\left(S_{-} W_{-}\right.$02) in which the children added their own interpretation to elements identified in the pictures was significantly greater (situation S+ median: 6, situation S- median: 8); Wilcoxon $Z=-1.779, p=0.0375$ (one-way significance). Also, there were more statements ( $\left.S_{-} W_{-} 03\right)$ with content not present in the pictures in S- (median: 10) than in S+ (median: 5.5); Wilcoxon $Z=-2.536, p=0.011$ (two-way significance).

Similar results were obtained for similarities and differences between $\mathrm{S}+$ and S- for statements introduced spontaneously and concentrating on: 
a) content present in the pictures ( $\left.S_{-} W_{s} p_{-} 01\right)$ : there were no significant differences in the number of statements referring to content present in the pictures;

b) content present with added interpretation (S_Wsp_02): also no statistically significant differences;

c) content not present in the pictures - new content (S_Wsp_03): here, there were more spontaneous statements in S- than in S+, Wilcoxon $Z=-1.778$, $p=0.038$ (one-way significance).

In response to the adult's questions in situation $S-$, children introduced more statements referring to content present in the pictures (S_Wpp_01): Wilcoxon $Z=-1.703, p=0.044$ (one-way significance) ${ }^{3}$. No differences were found for statements that referred to elements from pictures with added interpretation from the narrator (S_Wpp_02) in situation S+ and S-. In responses to questions in S- (compared to $S+)$ there were more statements with new content $\left(S \_W p p \_03\right)$, Wilcoxon $Z=-2.692, p=0.007$ (two-way significance).

\section{Analysis of the categories of information contained in the narrators' statements in $S+$ and $S$ -}

The children's stories were analyzed in terms of the categories of information contained in statements in S+ and S-.

The raters' task was to assign children's individual statements to seven categories whose classification was outlined above.

Information category 4 (S_Ki_04), event elaborations, was represented much more often in S- (median: 9.5) than in S+ (median: 5). The difference is statistically significant: Wilcoxon $Z=-3.484, p<0.005$ (two-way test).

Differences to the advantage of situation $S-$ were also found for information category 6, evaluations, (S_Ki_06): Wilcoxon $Z=-2.060, p=0.039$ (in the two-way test). As regards the other five information categories, no differences were found between S+ and S- in the narrators' introduction of content from these categories (item labels, item elaborations, events, explanations, reference to one's own experiences). Figure 3 presents the significant median differences in the information categories contained in the statements.

\section{Replies to "why?" questions in S+ and S-}

The following types of explanations appeared in response to "why?" questions:

\footnotetext{
${ }^{3}$ The result is statistically significant even though the zero median values suggest there were no differences. The median is equal to zero because out of 24 observations in the S+ group, 20 observations had zero values, one had a value of 1 , two had a value of 2 and one had a value of 3 . In all, in S+ the observations totaled $8(\Sigma 8)$, the average was 0.333 , and the median was 0 . In situation S-, out of 24 observations 17 had zero values, one had a value of 1 , two had values of 2 , one had a value of 3, two had a value of 4 and one had a value of 7. In all, in S- the observations totaled $23(\Sigma 23)$, the average was 0.958 , and the median was 0 . In situation S- children produced more statements in response to questions.
} 
Figure 3. Medians for the number of statements in situation S+ and S-, by information category

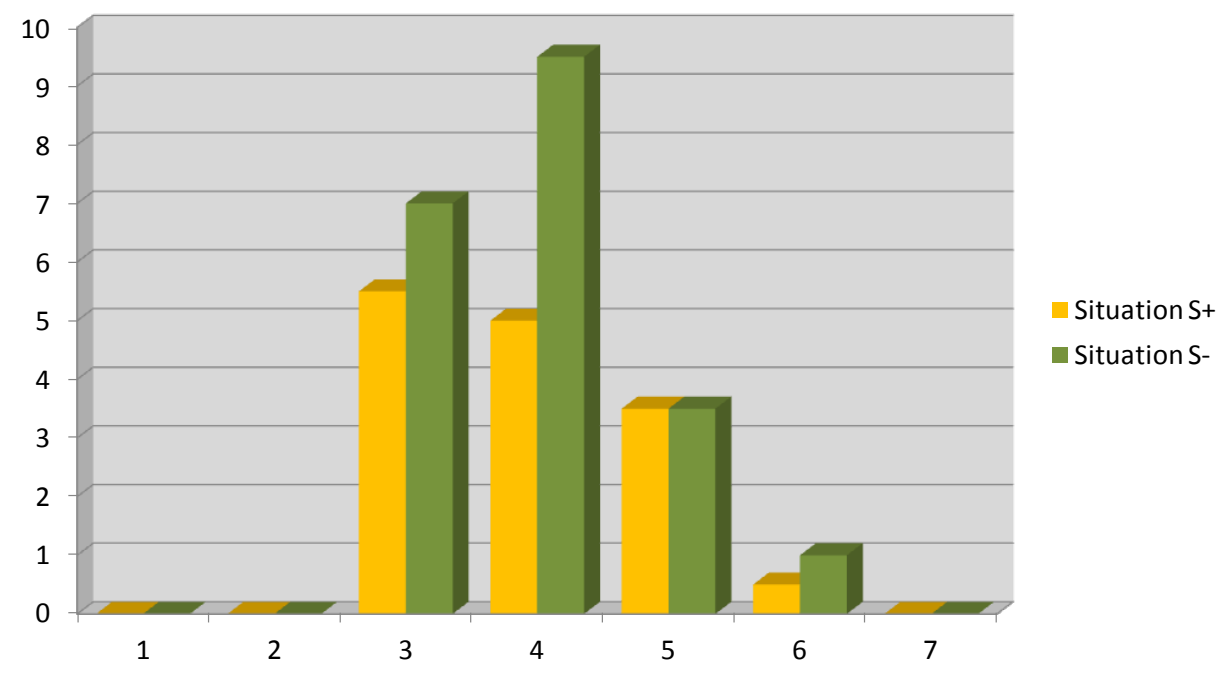

I. Justification and motivation $\left(S_{-} K W_{-} 01\right)$

II. Cause explanation $\left(S_{-} K W_{-} 02\right)$

III. Proof and logic $\left(S_{-} K W_{-} 03\right)$

IV. Repetition $\left(S_{-} K W_{-}\right.$04)

Analyzing the average numbers of replies containing the different types of explanations, no statistically significant difference was found in the replies to "why?" questions between situations S+ and S-.

\section{Logistic regression analysis}

To determine which variables related to children's statements are most typical for situations S+ and S-, models involving regression were built. In this analysis, the narrative situation was treated as a dependent (outcome) variable. Because it only assumes two categories (S+, S-), logistic regression was applied. The children's statement variables were the predictors.

Since the children's statement variables were collinearly dependent, several regression models were built, each time introducing those predictors that were not collinearly dependent. Eight models were built in all. We present the results of only four, chiefly because the other models did not reveal variables typical for situations S+ and S-.

Model one was built using the following predictors: content present, content present with interpretation, new content (variables $S_{-} W_{-} 01$ to $S_{-} W_{-} 03$ ). 
Table 2. Classification for model one calculated using logistic regression

\section{Classification table ${ }^{a}$}

\begin{tabular}{|c|c|c|c|c|c|}
\hline & & & & & \\
\hline & Observ & & & & Percent of correct \\
\hline & & & S- & S+ & classifications \\
\hline & Citution & S- & 13 & 11 & 54.2 \\
\hline Step 1 & Situation & $\mathrm{S}+$ & 5 & 19 & 79.2 \\
\hline & Overall $\mathrm{p}$ & entage & & & 66.7 \\
\hline
\end{tabular}

a The dividing point is the value 0.500

Model two was built using the following predictors related to spontaneous statements and to prompted statements (after questions): content present in the pictures (respectively: $\left.S_{-} W s_{0} p_{01}, S_{-} W p p_{-} 01\right)$, content present in the pictures with interpretation $\left(S \_W s p \_02, S_{-} W p p \_02\right)$, new content $\left(S \_W s p \_03, S \_W p p \_03\right)$.

Model three was built using variables related to information categories opened up by the adult's questions (respectively from $S_{-}$Kip_01 to $S_{-}$Kip_04, see Appendix 3).

Model four was built using the sum of statements: the average sum of all statements $S \_W$-sum (text length), the sum of spontaneous statements $S_{\text {_ }} W$ sp_sum, the sum of statements after questions $S_{-}$Wpp_sum, the sum of information in questions.

In successive stages, the logistic regression analysis provided the four most important variables for the models:

In model one, regression analysis included the variable $S_{-} W_{-} 03-$ the average number of statements with new content (going beyond what was given in the pictures), $\beta=(-0.147), p=0.035$. This variable is weakly negatively correlated with situation $\mathrm{S}+$. With this variable, the model can perform $66.7 \%$ correct classifications on average, where $79.2 \%$ concern situation $\mathrm{S}+$ and $54.2 \%$ concern situation S-. Thus, information that new content appears less often in children's statements (overall) enables the model to correlate them with category $\mathrm{S}+$ (a greater number of statements with new content is related to situation $\mathrm{S}-$ ).

The Hosmer-Lemeshow test revealed that the model fits the data well, as shown by the insignificant value of the statistic $C h i^{2}(7)=7.574, p=0.372$.

In model two, regression analysis included the variable of statements with new content in response to the adult's questions ( $\left.S_{-} W p p_{-} 03\right): \beta=-0.347, p=0.014$. This variable is weakly negatively correlated with situation $\mathrm{S}+$. With this variable, the model can perform $70.8 \%$ correct classifications on average, where 
Table 3. Classification for model two calculated using logistic regression

\section{Classification table ${ }^{a}$}

\begin{tabular}{|c|c|c|c|c|c|}
\hline & \multirow{3}{*}{\multicolumn{2}{|c|}{ Observed }} & \multicolumn{3}{|c|}{ Predicted } \\
\hline & & & \multicolumn{2}{|c|}{ Situation } & \multirow{2}{*}{$\begin{array}{l}\text { Percent of correct } \\
\text { classifications }\end{array}$} \\
\hline & & & S- & $\mathrm{S}+$ & \\
\hline \multirow{3}{*}{ Step 1} & \multirow{2}{*}{ Situation } & S- & 15 & 9 & 62.5 \\
\hline & & $\mathrm{S}+$ & 5 & 19 & 79.2 \\
\hline & \multicolumn{2}{|c|}{ Overall percentage } & & & 70.8 \\
\hline
\end{tabular}

a The dividing point is the value 0.500

$79.2 \%$ concern situation $\mathrm{S}+$ and $62.5 \%$ concern situation $\mathrm{S}-$. Thus, information that new content appears less often in children's statements prompted by the adult's questions enables the model to predict that this concerns situation S+ (a greater number of statements with new content following questions is related to situation $\mathrm{S}-$ ).

The Hosmer-Lemeshow test revealed that this model also fits the data well, as shown by the insignificant value of the statistic $C h i^{2}(5)=3.025, p=0.696$.

In model three, regression analysis included the variable of statements elaborating on the events $\left(S_{-} K K_{-}\right.$04) in spontaneous statements and after questions, taken together: $\beta=(-0.235), p=0.05$. This variable is weakly negatively correlated with situation $\mathrm{S}+$. With this variable, the model can perform $70.8 \%$ correct classifications on average, where $79.2 \%$ concern situation $\mathrm{S}+$ and $62.5 \%$

Table 4. Classification for model three calculated using logistic regression

\section{Classification table ${ }^{a}$}

\begin{tabular}{|c|c|c|c|c|c|}
\hline & \multirow{3}{*}{\multicolumn{2}{|c|}{ Observed }} & \multicolumn{3}{|c|}{ Predicted } \\
\hline & & & \multicolumn{2}{|c|}{ Situation } & \multirow{2}{*}{$\begin{array}{l}\text { Percent of correct } \\
\text { classifications }\end{array}$} \\
\hline & & & S- & $\mathrm{S}+$ & \\
\hline \multirow{3}{*}{ Step 1} & \multirow{2}{*}{ Situation } & S- & 15 & 9 & 62.5 \\
\hline & & $\mathrm{S}+$ & 5 & 19 & 79.2 \\
\hline & \multicolumn{2}{|c|}{ Overall percentage } & & & 70.8 \\
\hline
\end{tabular}

a The dividing point is the value 0.500 
Table 5. Classification for model four calculated using logistic regression

\section{Classification table ${ }^{a}$}

\begin{tabular}{|c|c|c|c|c|c|}
\hline & & & & & \\
\hline & Observe & & & & Percent of correct \\
\hline & & & S- & $\mathrm{S}+$ & classifications \\
\hline & citulion & S- & 17 & 7 & 70.8 \\
\hline Step 1 & Situatron & $\mathrm{S}+$ & 8 & 16 & 66.7 \\
\hline & Overall p & entage & & & 68.8 \\
\hline
\end{tabular}

a The dividing point is the value 0.500

concern situation S-. Thus, information that statements elaborating on events appear less often enables the model to predict that this concerns situation $\mathrm{S}+$ (a greater number of statements elaborating on events is related to situation $\mathrm{S}^{-}$).

The Hosmer-Lemeshow test revealed that model three also fits the data well, as shown by the insignificant value of the statistic $C h i^{2}(6)=3.317, p=0.389$.

In model four, regression analysis included the variable of the sum of statements prompted by questions ( $\left.S \_W p p \_s u m\right), \beta=(-0.286), p=0.01$. This variable is weakly negatively correlated with situation $S+$. With this variable, the model can perform $68.8 \%$ correct classifications on average, where $66.7 \%$ concern situation S+ and $70.8 \%$ concern situation $\mathrm{S}-$. Thus, information about fewer statements appearing after questions enable the model to predict that this concerns situation $\mathrm{S}+$ (a greater number of statements after questions is related to situation $\mathrm{S}-$ ).

The Hosmer-Lemeshow test revealed that model four also fits the data well, as shown by the insignificant value of the statistic $C h i^{2}(7)=7.661, p=0.363$.

Figure 4. Summary of the logistic regression model results. The graph presents the relations between predictors and the situation variable (category $\mathrm{S}+$ )

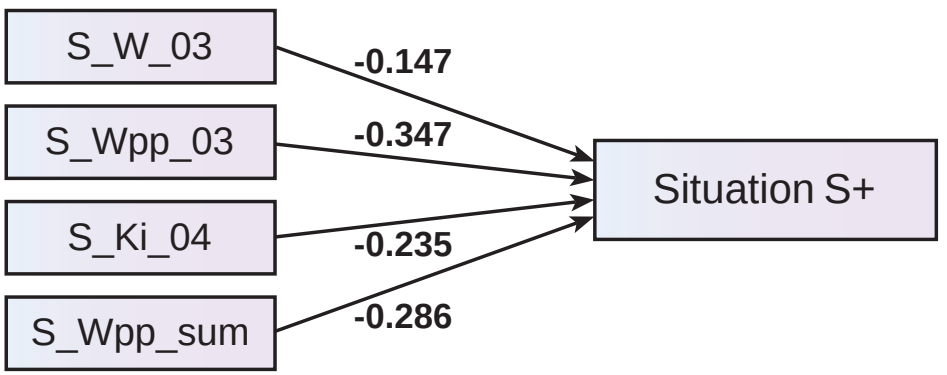


Summarizing the results of the logistic regression models: they revealed four variables that enable differentiation between situations S+ and S-. They are the variables of new content in children's statements, new content prompted by questions, elaborating on events, and the sum of statements prompted by questions. Figure 4 presents a graph with the logistic regression results ${ }^{4}$.

\section{Artificial intelligence algorithm}

The final analysis involved the construction of a decision tree using the Classification and Regression Tree (C\&RT) artificial intelligence algorithm. This algorithm uses predictors (variables related to children's statements) to explain children's participation in situation S+ and/or S-. Its aim is to indicate those variables which enable it to classify narrative texts as coming from situation S+ or S-, thus achieving homogeneity within groups. The algorithm operates until it achieves its aim, i.e. until, on the basis of predictors, it assigns texts to situation S+ and/or S-. Figure 5 presents the decision tree graph calculated with the C\&RT algorithm. In the first

Figure 5. Decision tree built using the Classification and Regression Tree (C\&RT)

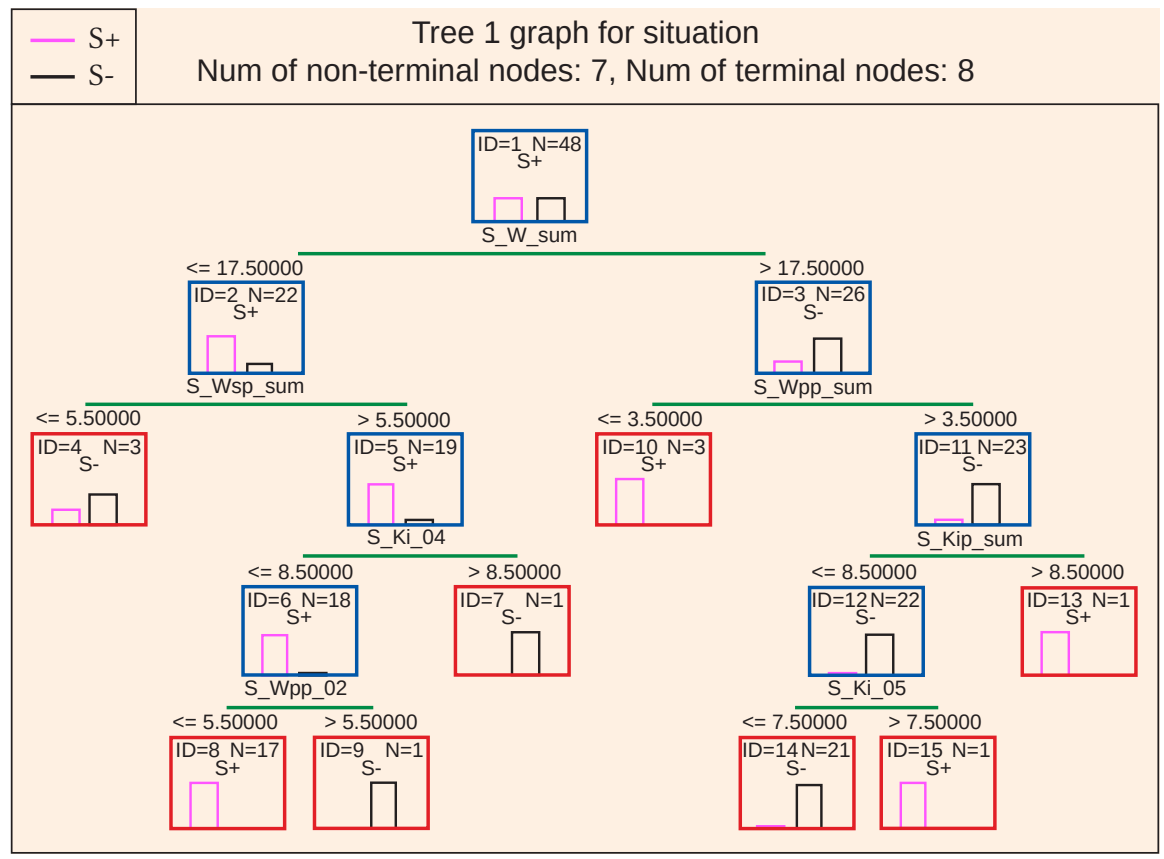

\footnotetext{
${ }^{4}$ The graph was produced using AMOS software. The calculations were not performed with the same software. This would have required indicating the relations between predictors, and the situation variable would have to have epsilon (remainder of the regression).
} 
window, the algorithm started from 48 observations $(N=48)$ : 24 related to situation S+ (pink bar) and 24 related to situation S- (black bar). All the predictors in the tree were treated as continuous, and not discrete, variables.

The first branch is formed by the number of statements in children's texts (length of narrative text $S_{-} W_{-}$sum). When texts were longer (having more than 17.5 statements), the algorithm linked them to the category of the outcome variable S-. This group contained 26 texts. Thus, longer narrative texts appeared in situation S-. This is in full agreement with the results of earlier analyses. In this way the algorithm found the first partitioning between texts produced by the same children in situations S+ and S-. There were 22 shorter texts and the algorithm linked them to situation $S_{+}$.

Within the longer and shorter texts, each group being inhomogeneous, the algorithm carried out consecutive functions to differentiate between them.

Thus, the algorithm differentiated the group of longer texts (26) using the variable of the sum of statements after questions (S_Wpp_sum). When the number of statements after questions in a narrative text was greater than 3.5, the algorithm linked it to situation S-. This group included 23 texts. The algorithm then differentiated these texts with the help of the variable of the number of statements with content from the explanation information category $\left(S \_K i\right.$ 05). When there were no more than 7.5 such statements in the texts, the algorithm linked them to situation S- (21 texts).

The algorithm differentiated the group of shorter texts (22) using the variable of the sum of spontaneous statements (S_Wsp_sum). When the number of spontaneous statements in a text exceeded 5.5, the algorithm linked it to situation $\mathrm{S}+$. This group included 19 texts. The algorithm then differentiated these texts with the help of the variable of the number of statements with content from the event elaboration category (S_Ki_04). When texts contained up to 8.5 such statements, the algorithm linked them to situation S+ (18 texts). These texts were then differentiated further using the variable of statements after questions, with content present in the pictures with interpretation added by the children (S_Wpp_02). When texts contained no more than 5.5 such statements on average, the algorithm linked the texts to situation $\mathrm{S}+$.

Summarizing the results obtained using the C\&RT artificial intelligence algorithm, the narrative texts associated with situation $\mathrm{S}+$ are characterized as follows: they are shorter texts (maximum 17.5 statements), containing more than 5.5 spontaneous statements on average, no more than 8.5 statements elaborating on events (spontaneous and after questions counted together), and no more than 5.5 statements prompted by questions and involving content present in the pictures with added interpretation.

Characterizing the narrative texts linked to situation S-, they are longer texts (more than 17.5 statements), containing more statements after the adult's questions (more than 3.5 statements). 
Table 6. Accuracy of the decision tree built using the C\&RT algorithm

\begin{tabular}{lccc}
\hline & Classified as S+ & Classified as S- & \% correctly classified \\
\hline Observed as S+ & 22 & 2 & $91.67 \%$ \\
Observed as S- & 0 & 24 & $100 \%$ \\
Overall accuracy of the tree for situation & variable S+ vs. S- & $95.84 \%$ \\
\hline
\end{tabular}

The model has a high level of accuracy. Based on the predictors (variables related to children's statements) indicated by the algorithm, it correctly classified $91.67 \%$ of observed texts as belonging to situation S+ and $100 \%$ in the case of S-. The model's accuracy is presented in the table below.

Some of the variables had a greater share, and others a smaller one, in building the decision tree. The importance of the variables is presented in Appendix 4. The largest contribution to the tree came from the following variables: number of statements with content elaborating on events $S_{-} K i_{-} 04$ (importance: 1), length of narrative texts $S_{-} W_{-}$sum (importance: 0.977), sum of statements after questions S_Wpp_sum (importance: 0.946), number of prompted statements (after questions) with content present in the pictures with added interpretation $S_{-}$Wpp_02 (importance: 0.933), number of prompted statements (after questions) with new content $S \_$Wpp_03 (importance: 0.904).

\section{Interpretation of results}

The results show unequivocally that the two situations are very different as two separate contexts for narratives produced by deaf children. The study, conducted on the same children taking part in situation S+ and in situation S-, showed that children in situation S- (when only the child sees the picture) build longer texts. On the other hand, when the adult can also see the picture that is the source of the conversation, children build shorter texts. The narrative text length $\left(S_{-} W_{-}\right.$sum $)$is the most important variable differentiating children's narrative activity in situation S+ and $\mathrm{S}-$. This is suggested by both the Wilcoxon statistics and the decision tree. Note that with this variable, the artificial intelligence algorithm not only created the first branch of the tree, but also found it sufficient to achieve almost complete homogeneity in the observed data. The number of statements produced by deaf children is what most strongly differentiates the two experimental situations. This result has profound implications, being the latest result confirming the situational diversity of children's verbal activity, not only in phonic (vocal-auditory) language, as earlier research has shown, but also in sign (visual-gestural) language. This effect achieved with 
deaf children is an effect having verification status. It confirms that narration is a function of knowledge about a situation possessed by the subject in the role of narrator (here: a deaf child)

Logistic regression indicated the variables of new content after questions (S_Wpp_03) and sum of statements after questions (S_Wpp_sum) as those that are the most strongly connected with story-building situations. These results are corroborated by the Wilcoxon test and the decision tree. The decision tree used the variable of the sum of statements after questions to create the second branch, and in terms of importance for the construction of the whole tree gives it third place. Therefore we can accept that statements after questions are the second variable sensitive to the changeability of the narrative discourse situation. Note, however, that a greater number of statements produced after questions in situation S- does not stem from the fact that more questions were asked in that situation. The research procedure was set up so that the number of questions would be the same in both situations. This is also confirmed by the Wilcoxon statistic $=-1.642, p=0.101$. There were no differences between situation $\mathrm{S}+$ and $S-$ in terms of the number of questions asked. A greater number of statements were produced in situation S- not because the children had to answer more questions, because they did not. Thus, the greater number of statements after questions is the effect of the special situation in which the children wanted to say more to someone who could not see the picture story, and the child was the only source of information about what happened in the pictures. Children behaved differently in situation $S+$ because the adult listener had the same direct access to the picture story as the child.

Another variable worth highlighting here, as it is prominent in three of our analyses, is the information category $\left(S_{-} K_{-} i_{0}\right.$ ) in which more statements elaborating on events appeared in S- compared to $S+$. This is a very important variable in the construction of the decision tree, forming the fourth branch and indicated by the algorithm as the most important in the tree's construction. This variable differentiates the discourse situations, as confirmed by the Wilcoxon statistic. Finally, this variable is also indicated by logistic regression. In situation $S-$ children present a more elaborate characterization of events in their texts.

The final two variables highlighted by at least two statistics are the type of content provided, namely new content not present in the pictures (S_W_03), and the number of spontaneous statements (S_Wsp_sum). "New content" was indicated both by the Wilcoxon statistic and by logistic regression as being characteristic of situation S-. For spontaneous statements, meanwhile, which formed the second branch of the decision tree, the Wilcoxon statistic shows that they are produced more often by children in situation S-. In the decision tree this variable had lower values for three shorter (nonspecific) texts in situation S-.

To conclude, children in situation S- produce longer texts in sign language, formulate more spontaneous statements, produce more statements after ques- 
tions, generally speaking elaborate more (compared to S+) on events ("event elaborations" information category), and add more new content going beyond the material available to perception. Children use their imagination more (what could have happened before and what could happen after the main events presented in the picture story), they use their knowledge about the possible inner states of the characters.

\section{Summary}

In summary, we can say that enabling a deaf child, just like a hearing child, to communicate his or her experiences to someone who does not share them with the child (the adult's lack of access to the source of the conversation topic, here: pictures) results in the child's more extensive contribution to narrative discourse. It helps children use their language skills more fully, whether the language is spoken (vocal-auditory) in the case of hearing children or signed (visual-gestural) in the case of deaf children.

Hence, children finding themselves in the role of a narrator in a given situation transform their perception of that situation into a task to be performed (cf. the theory of action of Tomaszewski (1984). Regardless of the modality of the language they use, children complete the narrative task similarly in a given situation, whether in a spoken or signed language. In situation S- children build longer texts (compared to $S+$ ), containing more spontaneous statements and more statements in response to questions. Furthermore, they compose texts carrying more information that elaborates on the events being recounted.

When children are the only source of information about a picture, they make more extensive use of their creative language skills. They go beyond what is available to their perception and supplement their stories with their own associations, experiences, ideas about past and future situations. They give the adult more information, adding references to their own knowledge, thoughts and experiences instead of just adding interpretations to whatever is visible in the picture.

The similarities in the performance of narrative tasks between hearing children and deaf children are undeniable. However, there is also an interesting difference. Earlier studies involving hearing children showed that children made significantly fewer references to the content present in the pictures in situation S- than in situation S+. The study presented here shows that deaf children produce the same number of statements presenting perceived content, while in response to the adult's questions in situation S- they introduce more statements, including more statements about content present in the pictures. This difference in results for hearing and deaf children is likely to be connected with the specificity of language modality. In order to express one's own associations and ideas related to a picture using sign language, one has to sign some information about the perceived pictorial material. Recounting the content of the pictures 
may but does not necessarily have to be the main purpose of the story. It could simply be a point of reference for more extensive and more detailed meanings assigned to the recounted events and provided to the interlocutor. It is our hope that analyses of the dynamics of content being transmitted in successive statements of narrative discourse in sign language will help resolve these questions.

\section{Final notes}

In their book How Deaf Children Learn. What Parents and Teachers Need to Know, Marschark and Hauser (2012) wrote: "If you were to look at the current scientific literature in deaf educational placement and practice as well as that concerning teaching and learning, you would find far less information than you might expect on how best to structure classrooms and instruction for deaf children. One reason for that is that there is far less research on how to teach deaf students than there is on how they learn" (ibid., p. 121).

Our study on deaf children composing stories in two different interactional conditions is our modest contribution to investigating how to best support deaf children's communicative skills. The data from this research illustrate the message formulated by Professor Grace Wales Shugar in the spirit of the idea of dual agentivity of adult-child interaction, which we would like to repeat here: It is only when children can show what they know in their own way, and when that child knowledge is received and used in a discourse process, that we can expect a child's inner motivation to acquire knowledge from others to be maintained and to become a driving force of the child's further development (Shugar, 1995, p. 233).

\section{Acknowledgments}

Grateful acknowledgment is due to the children who participated. This paper was supported by the Principal Research Fund of the Faculty of Psychology, University of Warsaw (BST 171223/2014).

\section{References}

Babska, Z. \& Shugar, G.W. (1984). Idea dwupodmiotowości interakcji dorosłydziecko $\mathrm{w}$ procesie wychowania $\mathrm{w}$ pierwszych latach życia [Idea of dual agentivity of adult-child interaction in early education]. Roczniki Filozoficzne KUL, 32 (4), 17-48.

Bałachowicz, J. (1996). Różnicowanie kontekstu społecznego wypowiedzi przez dzieci lekko upośledzone umysłowo [Differentiation of the social context of mentally retarded children's speech]. Kwartalnik Polskiej Psychologii Rozwojowej, 4 (2/3), 99-107. 
Bokus, B. (1991a). Children's pragmatic knowledge of narrative tasks. In J. Verschueren (Ed.), Pragmatics at Issue. Part I (pp. 13-28). Amsterdam: John Benjamins.

Bokus, B. (1991b). Tworzenie opowiadań przez dzieci. O linii i polu narracji [Children Building Stories. Narrative Line and Narrative Field]. Kielce: Energeia.

Bokus, B. \& Shugar, G.W. (1979). What will a three-year-old say? In O. Garnica \& M. King (Eds.), Language, Children and Society (pp. 249-269) Oxford: Pergamon Press.

Bokus, B. \& Shugar, G.W. (1995). Analiza tekstu tworzonego przez dziecko w dyskursie narracyjnym (Wybór treści znanych i nie znanych odbiorcy). [Analysis of text created by children in narrative discourse (Choice of content known or unknown to the listener)]. In G.W. Shugar, Dyskurs dziecięcy. Rozwój w ramach struktur spolecznych [Child Discourse. Development in the Framework of Social Structures] (pp. 105-118). Warszawa: Energeia.

Bokus, B. \& Shugar, G.W. (1998). Social structures of children's narrational activity. Psychology of Language and Communication, 2 (1), 75-81.

Cazden, C.B. (1970). The neglected situation in child language research and education. In F. Williams (Ed.), Language and Poverty: Perspectives on a Theme (pp. 81-101). Chicago: Markham.

Geppertowa, L. (1968). Rozwój rozumienia i posługiwania się przez dzieci pojęciami stosunków określanymi przez przyimki i spójniki [Development of children's understanding and using concepts of relations described by prepositions and conjunctions]. In S. Szuman (Ed.), O rozwoju języka i myślenia dziecka [On Development of Child Language and Cognition] (pp. 149-381). Warszawa: PWN.

Gurycka, A. (Ed.) (1989). Podmiotowość w doświadczeniach wychowawczych dzieci i mtodzieży. Cz. 3 [Agentivity in Educational Experiences of Children and Adolescents. Vol. 3]. Warszawa: Wydawnictwa Uniwersytetu Warszawskiego.

Halliday, M.A.K. (1975). Learning how to mean. In E.H. Lenneberg \& E. Lenneberg (Eds.), Foundations of Language Development. Vol. 1 (pp. 239-264). Paris: The UNESCO Press and Academic Press.

Halliday, M.A.K. \& Hasan, R. (1976). Cohesion in English. London: Longman.

Kende, M. (1984). Öt törtonét két manóról. Budapest: Minerva.

Kurcz, I. (2005). Psychologia języka i komunikacji [Psychology of Language and Communication]. Warszawa: Scholar.

Labov, W. (1972). The study of language in its social context. In J.B. Pride \& J. Holmes (Eds.), Sociolinguistics (Selected Readings) (pp. 180-202). Harmondsworth: Penguin Books.

Labov, W. \& Waletzky, J. (1967). Narrative analysis: Oral version of personal experience. In J. Helm (Ed.), Essays on the Verbal and Visual Arts (pp. 12-44). Seattle: University of Washington Press. 
Marschark, M. \& Hauser, P.C. (2012). How DeafChildren Learn. What Parents and Teachers Need to Know. Oxford: Oxford University Press.

Nelson, K. (2014). A matter of meaning: reflections on forty years of JCL. fournal of Child Language, 41 (Suppl. 1), 93-104.

Modzelewska, U. (1996). Dziecko-narrator w roli dziennikarza radiowego i telewizyjnego. Wybór treści znanych i nie znanych odbiorcy [Child narrator in the role of radio and television journalist. Choice of content known and unknown to the listener]. M.A. Thesis. University of Warsaw, Faculty of Psychology.

Shugar, G.W. (1978). Text analysis as an approach to the study of early linguistic operations. In N. Waterson \& C. Snow (Eds.), Development of Communication (pp. 227-251). Chichester: Wiley.

Shugar, G.W. (1995). Dyskurs dziecięcy. Rozwój w ramach struktur społecznych [Child Discourse. Development in the Framework of Social Structures]. Warszawa: Energeia.

Shugar, G.W. (1998). Entry into narration. Uses of operations of reference. Psychology of Language and Communication, 2(2), 7-16.

Shugar, G.W. \& Bokus, B. (1988). Twórczość językowa dziecka w sytuacji zabawowozadaniowej [Children's Language Creativity Studied in Play Task Situations]. Wrocław: Ossolineum.

Shugar, G.W., Bokus, B., \& Smogorzewska, J. (2013). From Reference Situation to Narrative Text. Warszawa: Lexem.

Snow, C. \& Goldfield, B.A. (1982). Building stories: The emergence of information structures from conversation. In D. Tannen (Ed.), Analyzing Discourse: Text and Talk (pp. 127-141). Washington, DC: Georgetown University Press.

Tarwacka, A. (2004). Dyskurs narracyjny dzieci głuchych w interakcji z dorosłym [Deaf children's narrative discourse in interaction with an adult]. M.A. Thesis. University of Warsaw, Faculty of Psychology.

Tomaszewski, P. (2010). Fonologia wizualna Polskiego fezyka Migowego [Visual Phonology of Polish Sign Language]. Warszawa: Matrix.

Tomaszewski, T. (1984). Ślady $i$ wzorce [Traces and Patterns]. Warszawa: WSiP.

Trevarthen, C. (1980). The foundations of intersubjectivity: Development of interpersonal and cooperative understanding of infants. In D.R. Olson (Ed.), The Social Foundations of Language and Thought: Essays in Honor of F.S. Bruner (pp. 316-342). New York: W.W. Norton.

Turnbull, L. (1980). The effects of situational factors on child speech. In M. Nixon (Ed.), Studies of Developmental Psycholinguistics. Research Monograph (pp. 26-36). Clayton, VIC: Monash University, Faculty of Education. 


\section{Appendix 1.}

The picture stories (A and B)

A
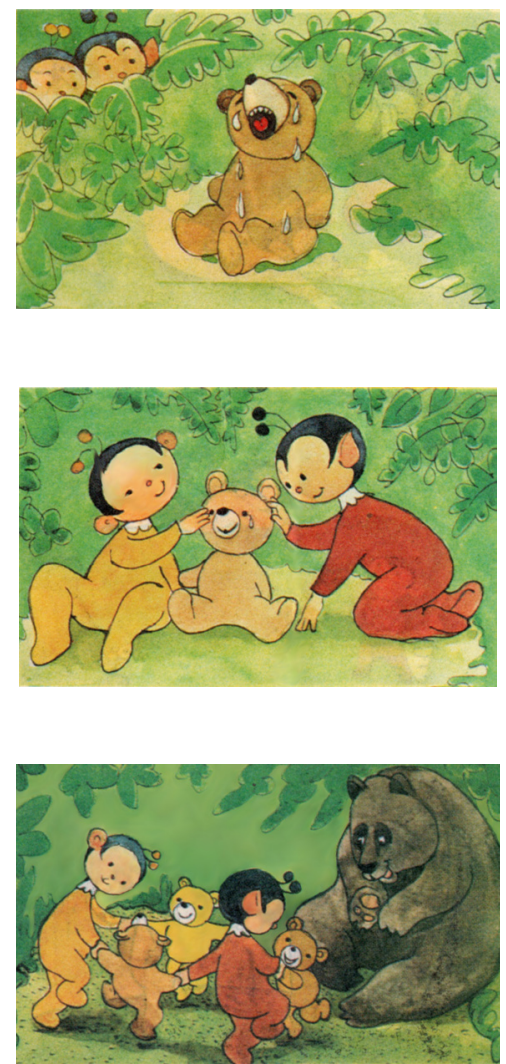

B
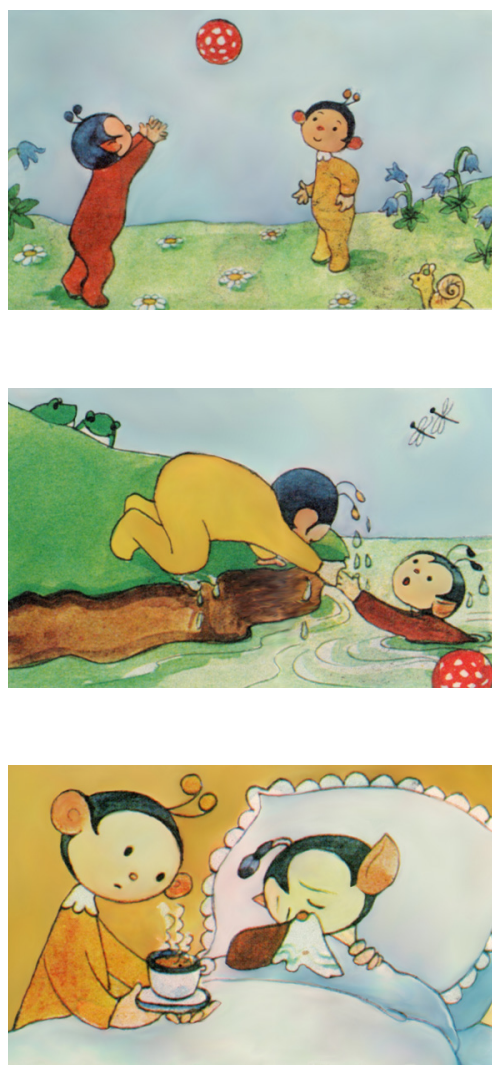


\section{Appendix 2. \\ Sample text (randomly chosen from the group of deaf children taught by the bilingual method) produced by one of the deaf children in two experimental situations (S+ and $\mathrm{S}-$ )}

\section{Situation S+}

MIŚ PŁAKAĆ+++, DZIEWCZYNKA PRZYJŚĆ GŁASKAĆ-misio, SPOKOJNY MIŚ Bear cries all the time. Girl comes and strokes bear. Bear calm himself down.

BABCIA DUŻA+, MIŚ++ MAŁE, DZIEWCZYNKA PRZYJŚĆ, GEASKAĆ, POMAGAĆ

Grandma is large and bears are small. Girl comes and strokes (bear). (She) helps (him).

BAWIĆ-SIĘ, TAŃCZYĆ, BAWIĆ-SIĘ.

(They) play and dance. (They) play.

(bold words: Teacher asks the child a question)

DLACZEGO PŁAKAĆ DLACZEGO wh-q

Why does (bear) cry?

DLACZEGO PŁAKAĆ DLACZEGO wh-q

Why does (bear) cry?

DLACZEGO

Why?

PRZYJŚĆ NIE-CHCIEĆ, PRZYJŚĆ NIE-CHCIEĆ (Nobody) does not want to come.

UŚMIECHAĆ-SIE DLACZEGO wh-q

Why does (bear) smile?

GŁASKAĆ, USPOKOIĆ, GŁASKAĆ

(Girl) strokes (bear) and calms (herself) down. (She) strokes (bear). 


\section{Situation S-}

BAWIĆ-SIĘ, ODBIJAĆ-PIŁKA, PIŁKA ODBIJAĆ-PIEKA, BAWIĆ-SIĘ++++ (They) play. (They) bounce a ball. (They) bounce a ball. They play all the time.

-_wh-q

Who?

DZIEWCZYNKA CHŁOPIEC, CHŁOPIEC DZIEWCZYNKA BAWIĆ-SIE,, Girl and boy. Girl and boy play.

ODBIJAĆ-PIEKA, BAWIĆ-SIĘ, (They) bounce the ball. (They) play.

WPAŚĆ-DO-wody, CZERWONY MOKRY, PŁYWAĆ++, MOKRY, (He) falls into water. (Boy) in red (clothes) gets wet. (He) swims. (He) is all wet.

POMAGAĆ-mu ŻÓłTY, WYCIĄGAĆ-go $z$ wody, POMAGAĆ-mu+, ZMĘCZYĆSIE,

(Girl) in yellow (clothes) helps him. (She) pulls him out of the water. (She) tires (when pulling him).

POMAGAĆ-mu, CHORY CZERWONY, CHORY+++, POMAGAĆ+, PICIE, CHUSTECZKA KATAR DAĆ-mu, ŻÓŁTE UBRANKO DAĆ-mu

(Girl) helps him. (Boy) in red (clothes) is sick. (He) is gravely ill. (She) assists (him). (Girl) in yellow clothes gives him drink and tissue. (He have) a runny nose.

CHORY CZERWONY, CHORY+

(Boy) in red (clothes) is sick. (He) isill.

DLACZEGO CHORY DLACZEGO

wh-q

Why is (he) sick?

wh-q

DLACZEGO, WPAŚĆ-DO WODA, PŁYWAĆ, PIŁKA WRZUCIĆ-DO-wody, PIEKA PŁYWAĆ, UWAŻAĆ.

Why? (He) fell into water and swam. The ball fell into the water and floated. (One) has to be careful. 


\section{Appendix 3. \\ Transcription conventions: symbols used to write the sign system}

\begin{tabular}{ll}
\hline Symbol & Example \\
\hline WORD & MIŚ 'bear', PIŁKA 'ball' \\
& \\
& BAWIĆ-SIĘ 'to play' \\
& ODBIJAĆ-PIŁKA 'bounce a ball' \\
& \\
++ & $\begin{array}{l}\text { MIŚ } \\
++\end{array}$ \\
& PŁAKAĆC +++ \\
++ & 'cry all the time'
\end{tabular}

IX-pro1p 'me', IX-pro2p 'you'

IX

IX-pro3p 's/he' or 'it'

IX-picture 'this picture'

$\mathrm{X}$-boy picture 'this boy'

\section{CHŁOPIEC DZIEWCZYNKA}

BAWIĆ-SIĘ, ODBIJAĆ-PIŁKA,

'Girl and boy play. They bounce a ball.'

\section{Explanation}

A Polish word in capital letters stands for a Polish Sign Language (PJM) "word" (this word is called a gloss). The meaning of the PJM sign and the Polish word may not be exactly the same. The English translation is given next to the glossed word.

When the words for sign glosses are separated by a hyphen, they represent a single sign.

Each plus sign indicates a repetition of the sign. Several pluses denote a plurality of things, objects or people. The symbol is also used for habitual and frequentative inflection.

Short for INDEX, IX indicates pointing and is used for first, second, third person pronouns or objects. Specific referents are indicated by abbreviation symbols - prolp, pro2p, pro3p - meaning pronouns or words denoting the names of objects (e.g. pictures).

A comma indicates a syntactic break, signaled by a body shift and/or a change in facial expression (and usually a pause).
WPAŚĆ-DO-wody 'fall into water'

WYCIĄGAĆ-kogoś $z$ wody 'pull somebody out of the water'

ona/on-POMAGAĆ-mu 'S/he helps him' ona/on-DAĆ-mu 'S/he gives to him'

NHS:

NHS: TAK 'yes', NHS: NIE 'no’
Spatial or locative information about a sign is italicized, immediately after the sign gloss.

Specific symbols meaning pronouns before and after inflecting verbs indicate the subject and object of the verb.

Signs produced without the use of a hand are called "non-handed signs" (glossed as NHS).

These are symbols for non-manual behaviors. Wh-question: eyebrows wrinkled, head tilted. 


\section{Appendix 4.}

\section{Predictor importance}

\begin{tabular}{|c|c|c|}
\hline & Variable - rank & Importance \\
\hline S_Ki_04 & 100 & 1.000 \\
\hline S_W_sum & 98 & 0.977 \\
\hline S_Wpp_sum & 95 & 0.946 \\
\hline$S_{-} W p p_{-} 02$ & 93 & 0.933 \\
\hline$S \_W p p \_03$ & 90 & 0.904 \\
\hline S_Ki_05 & 78 & 0.782 \\
\hline S_Kip_sum & 73 & 0.731 \\
\hline S_W_03 & 70 & 0.704 \\
\hline$S_{-} W_{-} 02$ & 70 & 0.702 \\
\hline S_So_01 & 64 & 0.641 \\
\hline S_Wsp_sum & 63 & 0.627 \\
\hline S_Ro_02 & 62 & 0.618 \\
\hline S_Kip_03 & 58 & 0.576 \\
\hline S_Ki_03 & 57 & 0.572 \\
\hline$S \_K w_{-} 03$ & 56 & 0.556 \\
\hline S_Wsp_01 & 54 & 0.537 \\
\hline S_Ro_01 & 52 & 0.518 \\
\hline S_Wsp_03 & 49 & 0.494 \\
\hline S_So_03 & 49 & 0.488 \\
\hline S_So_02 & 49 & 0.486 \\
\hline S_Ki_02 & 47 & 0.467 \\
\hline$S \_W \_01$ & 45 & 0.451 \\
\hline S_Wsp_02 & 44 & 0.443 \\
\hline S_Kip_01 & 41 & 0.413 \\
\hline S_Ki_06 & 30 & 0.303 \\
\hline$S \_K w \_01$ & 26 & 0.263 \\
\hline$S \_W p p \_01$ & 23 & 0.228 \\
\hline$S \_R o \_03$ & 23 & 0.233 \\
\hline S_Ro_04 & 18 & 0.184 \\
\hline$S_{-} K w_{-} 02$ & 18 & 0.181 \\
\hline S_Ki_01 & 18 & 0.178 \\
\hline S_Kip_02 & 10 & 0.102 \\
\hline$S \_K w_{-} 04$ & 6 & 0.064 \\
\hline S_Kip_04 & 5 & 0.049 \\
\hline S_Ki_07 & 0 & 0.000 \\
\hline
\end{tabular}

